International Journal of Applied Linguistics \& English Literature

ISSN 2200-3592 (Print), ISSN 2200-3452 (Online)

Vol. 1 No. 7; November 2012 [Special Issue on Applied Linguistics]

\title{
The Impact of Task Complexity and Strategic Planning Time on EFL Learners' Accuracy and Fluency in Written Task Production
}

\author{
Asghar Salimi \\ Assistant Professor, Faculty of Humanities, University of Maragheh, Maragheh, Iran \\ Islamic Azad University, Urmia Branch, Urmia, Iran \\ Tel: 0098-481-226-4041E-mail: Asgharsalimi356@gmail.com \\ Parviz Alavinia (Corresponding author) \\ $\mathrm{PhD}$, Assistant Professor \\ Faculty of Humanities and Letters, Urmia University \\ Valfajr 2 Blvd., Urmia, West Azerbaijan, Iran
}

Tel: 00980441 3362008-12, E-mail: pevinia2006@yahoo.com

PO Box: 5719884375

Parvin Hosseini

Islamic Azad University, Urmia Banch, Urmia, Iran

Ali Shafaei

Islamic Azad University, Urmia Branch, Urmia, Iran

Received: 08-09- 2012

doi:10.7575/ijalel.v.1n.7p.104
Accepted: 25-10- 2012

Published: 25-11- 2012

URL: http://dx.doi.org/10.7575/ijalel.v.1n.7p.104

\begin{abstract}
The past twenty years has witnessed a remarkable increase in the number of studies investigating different aspects and features of tasks in the second and foreign language class and their effects on learners' oral and written task performance. Building up on a review of the studies conducted in the field of task-based language teaching a gap was revealed in the literature on the joint effects of task complexity and types of pre-task planning on L2 learners' performance. The present study investigates the effects of strategic pre-task planning time and task complexity on a group of L2 learners' written performance in terms of accuracy and fluency. The means of accuracy and fluency of 50 intermediate English language learners, both male and female, chosen randomly from Iran National Language Institute, Miandoab Branch were compared using T-test as the statistical means of analysis. The findings revealed a positive influence of pre-task strategic planning time in both simple and complex tasks, suggesting significant implications for syllabus and task designers, language teachers, and SLA researchers.
\end{abstract}

Keywords: Task-based language teaching, Planning time, Strategic planning, Task complexity, Accuracy, Fluency

\section{Introduction}

Second or foreign language learners' oral and written task performance can be affected by different factors. One of these factors is the task type which the learners perform. Tasks have different features, all of which can affect L2 learners' performance in terms of accuracy, fluency, and complexity (task structure, topic familiarity, task condition, planning time, task complexity, and the generic features of the task). This paper will focus on planning time and task complexity. According to Ellis (2005), planning time in the field of task-based language teaching can be divided into pre-task (rehearsal and strategic) and within-task planning in terms of when planning takes place. As it is understood from the titles of the first type, planning happens before the performance of task. 
International Journal of Applied Linguistics \& English Literature

ISSN 2200-3592 (Print), ISSN 2200-3452 (Online)

Vol. 1 No. 7; November 2012 [Special Issue on Applied Linguistics]

Since the 1990s, many studies have been carried out on the effect of different task characteristics on L2 learners' performance (Skehan and Foster, 1999; Elder and Wigglesworth, 2003; Ellis, 2005, 2008; Philp et al, 2006; Rahimpour, 2008; Wang, 2008; Mehrang and Rahimpour, 2010; Dadashpour, 2011; Shafaei, 2012, Salimi et al, 2012; Salimi and Dadashpour, 2012a, 2012b). Fewer studies have been devoted to the investigation of the joint effects of pre-task planning time and task complexity. To fill this gap, the present study set out to investigate the joint effects of task complexity and strategic pre-task planning on L2 learners' written performance in terms of accuracy and fluency.

\section{Literature Review}

\subsection{Task-based language teaching}

Task-based language teaching has become a burgeoning area of research in second and foreign language research (Long, 1985, 2007; Nunan, 1989; Long and Crookes, 1992; Robinson, 1995, 2001, 2007; Ellis 2003, 2005, 2009; Foster and Skehan, 1996, 1999; Skehan and Foster, 1999; Robinson and Gilabert, 2007; Tavakoli and Foster, 2008; Rahimpour, 2008, 2010; Mehrang and Rahimpour, 2010; Salimi and Dadashpour, 2010, 2012a, 2012b; Salimi et al, 2012). Task-based language teaching challenges mainstream views about language teaching, assuming that language learning will develop most successfully and effectively if teaching aims simply to create context and conditions in which the learners' natural language learning ability can be nurtured (Ellis, 2005).

According to Ellis (2009) TBLT is an approach for teaching second or foreign language that seems to engage learners in interactionally authentic language use language by getting learners to perform a series of tasks. This approach aims to enable learners to acquire a new language system as well as to proceduralize their existing knowledge .In other words, this approach tries to force L2 learners to use their own linguistic resources to learn a new language.

\subsection{Task definition}

The notion of task has been defined variously by different researchers (Long, 1985; Prabhu, 1987; Skehan, 1996; Breen, 2001; Bygate, Skehan, and Swain, 2001; Ellis, 2003; Tavakoli and Foster, 2008). According to Skehan (1998):

A task is an activity in which meaning is primary; there is some communication problem to solve; there is some sort of relationship to comparable real-world activities; task completion has some priority; the assessment of the task is in terms of outcome (p.95).

\subsection{Planning time and its justification}

According to Ellis (2005) planning is an inseparable part of all spoken and written language use. That is, all speakers and writers need to decide what to say and write and how to do it. It involves allocation of attentional resources and regulation of cognitive processes (Yuan, 2001). Planning time has been investigated in various studies on second language production (Yuan, 2001; Yuan and Ellis, 2003; Tavakoli and Skehan, 2005; Tavakoli and Foster, 2008). Theoretical background in task-based and second language acquisition (SLA) research can be found in a) Tarone's (1983) account of stylistic variation, b) the models of speech production and writing (Levelt,1989) , c) the cognitive models of L2 performance and language learning (Skehan, 1998; Robinson, 2007). Also, Clark and Clark (1979) stated that planning takes place at a number of different levels, resulting in discourse plans, sentence plans, and consistent plans, all of which have to be interwoven in the actual execution of language.

\subsection{Types of task planning}

According to Ellis $(2005$, p. 3) task planning is divided into two main types. This distinction is in terms of when planning takes place. Pre-task planning refers to planning that takes place before performing the task. It involves what Schmidt (2001) calls 'prepatory attention' that helps in performing actions with greater accuracy and speed. The other type of planning time is within-task planning which refers to planning that takes place while performing the task. Each of these two types is divided into two other types.

Pre-task planning is divided into rehearsal and strategic planning. In rehearsal, learners are given the opportunity to "perform the task before the 'main performance" (Ellis, 2005, p. 3). That is, the performance of the task for the first time is regarded as a preparation for the main and final performance. On the other hand, strategic planning, 
International Journal of Applied Linguistics \& English Literature

ISSN 2200-3592 (Print), ISSN 2200-3452 (Online)

Vol. 1 No. 7; November 2012 [Special Issue on Applied Linguistics]

which is the focus of the present study, entails learners' preparation of the content of the task the learners will perform. In this type of planning, L2 learners "have access to the actual task materials" (Ellis, 2005, p. 3).

Within-task planning is also divided into pressured and unpressured planning. In pressured within-task planning, learners are usually not provided with enough time to plan on-line, while in unpressured within-task planning they are given enough time to plan the task they will perform on.

\subsection{Planning time studies}

Many studies have been conducted to investigate different types of planning time and their effects on L2 learners' performance in terms of accuracy, fluency, and complexity (Crookes, 1989; Foster and Skehan, 1996; Mehnert, 1998; Yuan and Ellis, 2003; Ellis and Yuan, 2004; Sangarun, 2005; Tavakoli and Skehan, 2005; Wang, 2008; Mehrang and Rahimpour, 2010). Yuan and Ellis (2003) studied the effect of pre-task and on-line planning on learners' monologic oral production. The results indicated that pre-task planning enhanced grammatical complexity, lexical variation and fluency while on-line planning positively influenced accuracy and grammatical complexity. However, the pre-task planning led to more fluent and lexically varied language than the on-line planning and the language produced by the two planning group (pre-task planning and on-line planning) was equally grammatically complex. Additionally, the on-line planning led to more accurate language than pre-task planning. Mehrang and Rahimpour (2010) studied the effects of task structure and planning time on oral performance of EFL learners in terms of accuracy, fluency, and complexity of 64 upper-intermediate learners of English as a foreign language. Results indicated that planning time had no effects on the accuracy and fluency of the learner performance. However, it led to more complex performances when participants performed the unstructured, complex task.

\subsection{Task complexity and its justification}

It is a widely accepted idea that research into complexity of second language tasks is necessary to pedagogical decisions regarding the grading and sequencing of tasks for the purposes of syllabus design (Gilabert 2005, 2007; Long 2007; Rahimpour 1997, 1999, 2002, 2008; Robinson 1995, 2001, 2003, 2005, 2007; Robinson and Gilabert 2007; Hosseini and Rahimpour, 2010; Salimi and Dadashpour, 2010, 2012a, 2012b). According to Rahimpour (2002) there are three theoretical frameworks for task complexity which are based on research into first language acquisition (Brown and Bellugi, 1964), research findings from second language development (Meisel, 1987), and functional linguistic theory (Givon, 1989).

Robinson (2001) offers the following definition for task complexity:

Task complexity is the result of the attentional, memory, reasoning, and other information processing demands imposed by the structure of the task to the language learner. These differences in information processing demands, resulting from design characteristics, are relatively fixed and invariant (p.29).

Robinson (2001) attributes the complexity of the task into three factors including inherent characteristics of the task itself which is related to the nature of input, the task conditions, and the processing operations involved in completing the tasks and the outcome that is required. These factors according to Robinson (2001) come under the heading of task complexity. The complexity of a task is the valid criteria to be taken into account in designing a task and syllabus. The design of a syllabus requires that the content be sequenced in a way so as to facilitate maximum learning (Ellis, 2003, 2008; Skehan, 2003; Nunan, 1989; Robinson, 2001; 2007). In effect, this requires determining the complexity of individual tasks so that tasks can be matched to learners' level of development, this argument is in line with teachability and learnability hypothesis proposed by Pienemann (1985).

\subsection{Task complexity models}

Different models of task complexity have been proposed by different researchers (Brown and Yule, 1983; Long, 1985; Brindley, 1987; Candlin, 1987; Prabhu, 1987; Anderson and Lynch, 1988; Rahimpour, 1997, 1999; Robinson 2001, 2007).

The present study was based on Robinson's Triadic Framework of Task Complexity or Cognition Hypothesis $(2001,2007)$. This framework distinguishes three task components: task complexity, task conditions, and task difficulty. Robinson (2001) pointed out that the development of theoretically motivated, empirically substantiable, and pedagogically feasible sequencing criteria has long been acknowledged as a major goal of research aimed at operationalizing task-based approaches to syllabus design. To this end, he proposed 
International Journal of Applied Linguistics \& English Literature

ISSN 2200-3592 (Print), ISSN 2200-3452 (Online)

Vol. 1 No. 7; November 2012 [Special Issue on Applied Linguistics]

distinctions between cognitively defined task complexity, learner perceptions of task difficulty, and the interactive conditions under which tasks are performed. Robinson (2001, p.29) strongly argued that Task Complexity is the result of the attentional, memory, reasoning, and other information processing demands imposed by the structure of the task on the language learner. These differences in information processing demands, resulting from design characteristics, are relatively fixed and invariant. Task complexity will aid explain within learner variance when performing any two tasks. It is, also, argued that the cognitively simpler tasks will involve a lower error rate, and/or be completed faster.

\subsection{Task complexity studies}

Many studies have been conducted to investigate task complexity and its effects on L2 learners' performance in terms of accuracy, fluency, and complexity (Robinson, 2001, 2007; Gilabert, 2005; Ishikawa, 2006; Kuiken and Vedder, 2007, 2008; Rahimpour, 2007; Kim, 2009; Hosseini and Rahimpour, 2010, Salimi et al, 2011; Salimi and Dadashpour, 2010, 2012a, 2012b). Robinson (2001) found that complex tasks elicited less fluent, but more accurate and complex production than the simple tasks. Rahimpour (2007) studied the effect of task complexity on L2 learners' oral performance. The results showed that there-and-then task (complex task) led to more accuracy while here-and-now task (simple task) led to more complexity. In terms of fluency, here-and-now task led to more fluency than there-and-then task. Hosseini and Rahimpour (2010) investigated the effects of task complexity on L2 learners' written performance on narrative pictorial tasks of here-and- now and there-andthen. The results of the study demonstrated that cognitively more demanding task (there-and- then) were more fluent, but no significant effects on written narratives were observed on measures of accuracy and complexity. Salimi et al (2011) investigated the effect of task complexity on L2 learners' written performance. They found out that task complexity did not have a significant effect on accuracy. Regarding fluency of written production, it was revealed that task complexity had a significant effect on fluency of the learners. For complexity of written production, they found that L2 learners' written complexity was significantly affected by task complexity. That is, Complex task led to the production of more complex language in terms of syntactic mode. Salimi and Dadashpour (2012b) conducted a study to find out the effect of task complexity on L2 learners' language production. Their study was based on the comparison of two models of task complexity namely Robinson's Cognition Hypothesis and Skehan's Trade-off Model. They found out that task complexity led to an increase in the domains of fluency and complexity but not accuracy.

Having reviewed the findings of the previous studies conducted on planning time and task complexity, it was revealed that strategic planning time and task complexity and their joint effects on L2 learners' oral/written performance has rarely been explored in the literature and there is a gap in the literature on this topic. Therefore, the present study set out to investigate the impacts of task complexity and strategic pre-task planning on EFL learners' written performance in terms of accuracy and fluency.

\subsection{Research question and hypotheses}

On the basis of the above literature review, the present study aimed at investigating the following research question and research hypotheses:

$\mathbf{R Q}_{1}$ : What are the effects of task complexity and strategic planning time on L2 learners' written performance in terms of accuracy and fluency?

$\mathbf{H}_{\mathbf{0}}$ : There isn't any significant difference between task complexity and planning time and L2 learners' written performance in terms of accuracy.

$\mathbf{H}_{\mathbf{1}}$ : Strategic planning group while performing a simple task will produce more accurate written production than unplanned group.

$\mathbf{H}_{2}$ : Strategic planning group while performing a simple task will produce more fluent written production than unplanned group.

$\mathbf{H}_{3}$ : Strategic planning time group while performing complex task will produce more accurate written production than unplanned group.

$\mathbf{H}_{4}$ : Strategic planning time group while performing complex task will produce more fluent language production than unplanned group.

\section{Methodology}

\subsection{Participants}

The participants of the study were 50 male and female intermediate English language learners affiliated to Iran National Language Institute, Miandoab Branch, West Azerbaijan, Iran. The participants were from Turkish L1

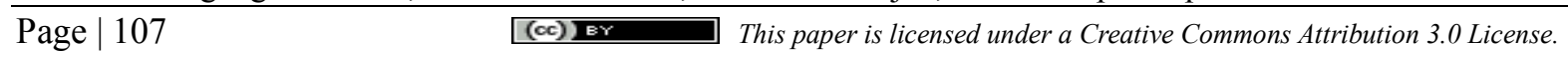




\section{International Journal of Applied Linguistics \& English Literature}

ISSN 2200-3592 (Print), ISSN 2200-3452 (Online)

Vol. 1 No. 7; November 2012 [Special Issue on Applied Linguistics]

language background attending a conversation course. In order to ensure about their homogeneity and their proficiency level, a pre-test was administered among the students. The participants of this study were selected randomly on the basis of their performance on the pre-test. Then, they were randomly assigned into two groups namely planned and unplanned groups.

\subsection{Data collection instrument}

Two versions of the same decision-making task (one simple and the other complex task) were taken from Gilabert (2007) and Salimi and Dadashpour (2012b). A simplified 'fire chief' task used in cognitive psychology was utilized. In this task, learners are presented with a building where a fire has broken out and where a number of people need to be rescued. The problem in the complex version required from learners not just one decision, but a long series, in which early decisions condition later ones. In both versions of the task learners were instructed to specify the actions they would take, determine the sequence of their actions, and justify their choice for actions and specific sequence. In the simple task, there are similar types of people (i.e. people with no particular roles) in the building who were faced with similar degrees of danger; the fire being relatively static, the smoke blowing away from the building. In the complex one, learners have to deal with specific types of people (e.g. a pregnant woman, an elderly man, an injured person, a hero).

\subsection{Procedure}

The data for this study was collected in two phases. First, the participants were asked to perform on the simple version of the decision-making task. In this phase, the planned group was asked to perform on the task with 10 minutes for strategic planning. The participants of unplanned group were asked to perform on the same task but they were not given any time for planning. After performing on the simple version of the task, the participants of both groups were asked to perform the complex version of the decision-making task. Of course, it should be noted that the participants performed on the complex version of the task after two weeks. This interval of two weeks was due to eliminating the memory effects. In this phase, the participants of planned group were given 10 minutes for strategic planning. Then, they were given the complex version of the task and were asked to perform on it. Then, the unplanned group's participants were asked to perform on the complex version of decision making task; however, they were not given any time for strategic planning. All the participants of both groups were given 40 minutes to perform the task. The collected data was quantified using the following accuracy and fluency measures.

\subsection{Accuracy measure}

The number error-free T-units per T-units (Arent, 2003; Rahimpour, 2008). T-unit is defined as "the main clauses plus subordinate clauses attached to or embedded in them" and error-free T-units are those T-units that contain no grammatical, lexical, or spelling errors.

\subsection{Fluency measure}

The fluency of the written production of the learners was measured by words per T-units. This measure was adopted by Ishikawa (2006) which means the total number of words divided by the number of T-units in the produced written text.

\section{Data Analysis and Results}

Table 1 clearly presents the means differences of accuracy of the written performance in simple task with and without strategic planning.

Table 1. Comparison of the Means of Accuracy of Written Performance in Planned and Unplanned Simple Task

\begin{tabular}{lcccc}
\hline & N & Mean & $\begin{array}{c}\text { Std. } \\
\text { Deviation }\end{array}$ & Std. Error Means \\
\hline $\begin{array}{l}\text { Planned Accuracy } \\
\text { Simple }\end{array}$ & 25 & 0.5828 & 0.16930 & 0.03386 \\
\hline $\begin{array}{l}\text { Unplanned Accuracy } \\
\text { Simple }\end{array}$ & 25 & 0.3908 & 0.11492 & 0.02298 \\
\hline
\end{tabular}

According to this table, the learners produced more accurate (0.58) language with strategic planning in simple task than without strategic planning (0.39). 
International Journal of Applied Linguistics \& English Literature

ISSN 2200-3592 (Print), ISSN 2200-3452 (Online)

Vol. 1 No. 7; November 2012 [Special Issue on Applied Linguistics]

Figure 1 shows the means differences of accuracy with and without strategic planning in simple task.

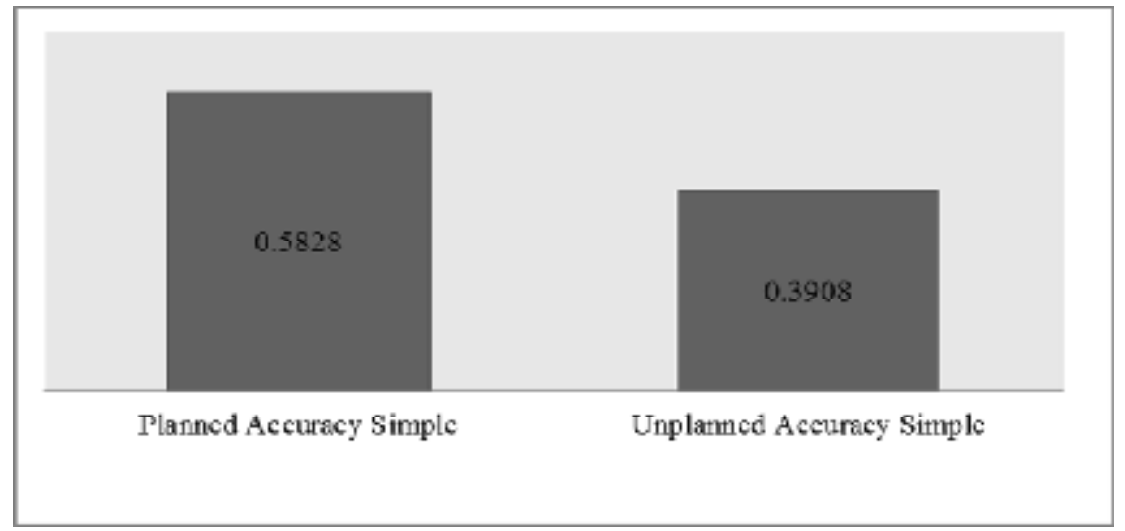

Figure 1. Comparison of the Means of Accuracy of Written Performance in Planned and Unplanned Simple Task

Table 2 shows the results of Independent Samples T-test for the means of accuracy of written performance of both groups in simple task.

Table2. Independent Samples T-Test for the Means of Accuracy of Written Performance in Planned and Unplanned Simple Task

\begin{tabular}{|c|c|c|c|c|c|c|c|c|c|}
\hline & \multicolumn{2}{|c|}{$\begin{array}{c}\text { Levene's Test for } \\
\text { Equality of Variances }\end{array}$} & \multicolumn{7}{|c|}{ t-test for Equality of Means } \\
\hline & \multirow[t]{2}{*}{$\mathrm{F}$} & \multirow[t]{2}{*}{ Sig. } & \multirow[t]{2}{*}{$\mathrm{t}$} & \multirow[t]{2}{*}{$\mathrm{df}$} & \multirow{2}{*}{$\begin{array}{l}\text { Sig. } \\
\text { (2-taile } \\
\text { d) }\end{array}$} & \multirow[t]{2}{*}{$\begin{array}{c}\text { Mean } \\
\text { Difference }\end{array}$} & \multirow[t]{2}{*}{$\begin{array}{l}\text { Std. Error } \\
\text { Difference }\end{array}$} & \multicolumn{2}{|c|}{$\begin{array}{c}95 \% \text { Confidence Interval of the } \\
\text { Difference }\end{array}$} \\
\hline & & & & & & & & Lower & Upper \\
\hline Independent & & & 4.69 & 48 & .000 & .19200 & .04092 & .10972 & 4.692 \\
\hline Samples Test & & & 2 & & & & & & \\
\hline Equal variances & 4353 & 0.04 & 4.69 & 42.244 & .000 & .19200 & .04092 & .10943 & 4.692 \\
\hline not assumed & 4.555 & 2 & 2 & & & & & & \\
\hline
\end{tabular}

Table 2 shows the results of statistical analysis of applying Independent Samples T-test to test the first hypothesis. The results of SPSS at $\mathrm{df}=48$ and $\alpha=.05$, suggested that there was a significant difference between strategic planning and L2 learners' accuracy in simple task. As a result, the first hypothesis claiming "strategic planning group while performing a simple task will produce more accurate written production than unplanned group" is confirmed.

Table 3 shows the means differences of fluency of written performance of the participants in simple task with and without strategic planning.

Table 3. Comparison of the Means of Fluency of Written Performance in Planned and Unplanned Simple Task

\begin{tabular}{lcccc}
\hline & N & Mean & $\begin{array}{c}\text { Std. } \\
\text { Deviation }\end{array}$ & $\begin{array}{c}\text { Std. Error } \\
\text { Means }\end{array}$ \\
\hline $\begin{array}{l}\text { Planned Fluency } \\
\text { Simple }\end{array}$ & 25 & 13.7288 & 3.69318 & 0.73864 \\
\hline $\begin{array}{l}\text { Unplanned Fluency } \\
\text { Simple }\end{array}$ & 25 & 11.9252 & 2.45883 & 0.49177 \\
\hline
\end{tabular}

According to table 3, the learners produced more fluent (13.72) language with strategic planning in simple task than unplanned group (11.92).

Figure 2 also shows the means differences of fluency for planned and unplanned groups in simple task. 
International Journal of Applied Linguistics \& English Literature

ISSN 2200-3592 (Print), ISSN 2200-3452 (Online)

Vol. 1 No. 7; November 2012 [Special Issue on Applied Linguistics]

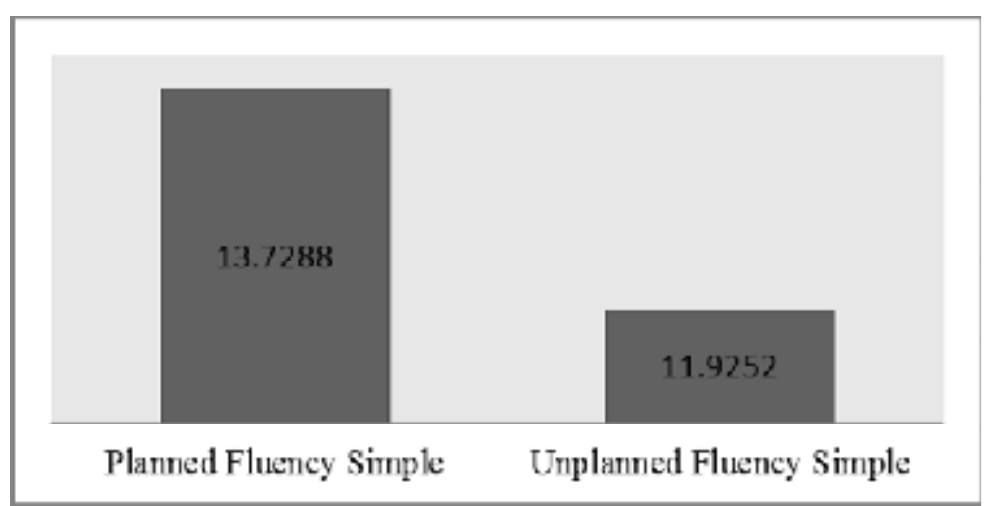

Figure 2. Comparison of the Means of Fluency of Written Performance in Planned and Unplanned Simple Task

Table.4 Independent Samples T-Test for the Means of Fluency of Written Performance in Planned and Unplanned Simple Task

\begin{tabular}{|c|c|c|c|c|c|c|c|c|c|}
\hline & \multicolumn{2}{|c|}{$\begin{array}{c}\text { Levene's Test } \\
\text { for Equality of } \\
\text { Variances }\end{array}$} & \multicolumn{7}{|c|}{ T-test for Equality of Means } \\
\hline & \multirow[t]{2}{*}{$\mathrm{F}$} & \multirow[t]{2}{*}{ Sig. } & \multirow[t]{2}{*}{$\mathrm{t}$} & \multirow[t]{2}{*}{$\mathrm{df}$} & \multirow[t]{2}{*}{$\begin{array}{l}\text { Sig. } \\
\text { (2-taile } \\
\text { d) }\end{array}$} & \multirow[t]{2}{*}{$\begin{array}{c}\text { Mean } \\
\text { Difference }\end{array}$} & \multirow[t]{2}{*}{$\begin{array}{l}\text { Std. Error } \\
\text { Difference }\end{array}$} & \multicolumn{2}{|c|}{$\begin{array}{l}95 \% \text { Confidence } \\
\text { Interval of the } \\
\text { Difference }\end{array}$} \\
\hline & & & & & & & & Lower & Upper \\
\hline $\begin{array}{l}\text { Independent } \\
\text { Samples Test }\end{array}$ & & & 2.033 & 48 & .048 & 1.80360 & .88736 & .01943 & $\begin{array}{c}3.5877 \\
7\end{array}$ \\
\hline $\begin{array}{l}\text { Equal } \\
\text { variances not } \\
\text { assumed }\end{array}$ & 2.059 & 0.158 & 2.033 & 41.783 & .048 & 1.80360 & .88736 & .01255 & $\begin{array}{c}3.5946 \\
5\end{array}$ \\
\hline
\end{tabular}

Table 4 shows the results of statistical analysis of applying Independent Samples T-test to test the second hypothesis. The results of SPSS at $\mathrm{df}=48$ and $\alpha=.05$, revealed that there was a significant difference between strategic planning and L2 learners' fluency in simple task. Thus, the second hypothesis claiming "strategic planning group while performing a simple task will produce more fluent written production than unplanned group" is confirmed.

Table 5 shows the means differences of accuracy of written performance of the participants in complex task with and without strategic planning.

Table 5. Comparison of the Means of Accuracy of Written Performance in Planned and Unplanned Complex Task

\begin{tabular}{lcccc}
\hline & N & Mean & $\begin{array}{c}\text { Std. } \\
\text { Deviation }\end{array}$ & $\begin{array}{c}\text { Std. Error } \\
\text { Means }\end{array}$ \\
\hline $\begin{array}{l}\text { Planned Accuracy } \\
\text { Complex }\end{array}$ & 25 & 0.4412 & 0.10651 & 0.02130 \\
\hline $\begin{array}{l}\text { Unplanned Accuracy } \\
\text { Complex }\end{array}$ & 25 & 0.3488 & 0.07672 & 0.01534 \\
\hline
\end{tabular}

The data presented in table 5 shows that the participants of planned group produced more accurate $(0.44)$ language than unplanned group in complex task (0.34).

Figure 3 also shows the means differences of accuracy for planned and unplanned groups in complex task. 
International Journal of Applied Linguistics \& English Literature

ISSN 2200-3592 (Print), ISSN 2200-3452 (Online)

Vol. 1 No. 7; November 2012 [Special Issue on Applied Linguistics]

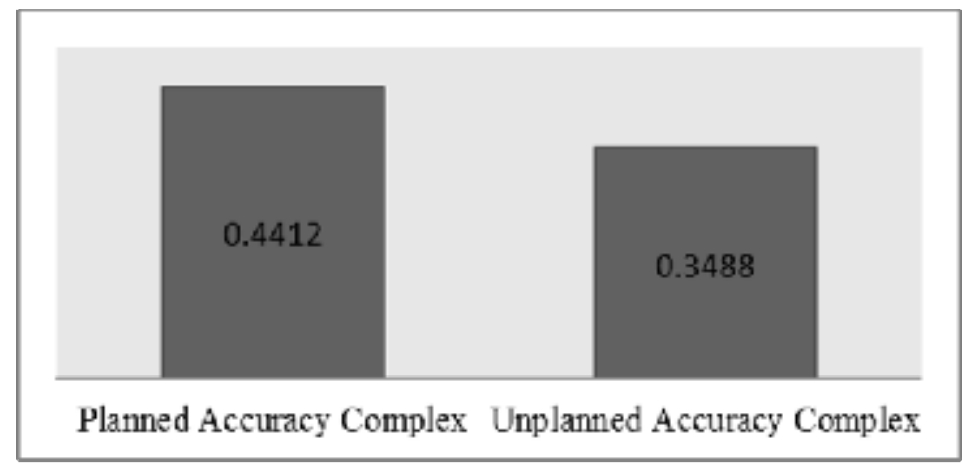

Figure 3. Comparison of the Means of Accuracy of Written Performance in Planned and Unplanned Complex Task

Table 6 shows the results of Independent Samples T-test for the means of accuracy of written performance of both groups in complex task.

Table 6. Independent Samples T-Test for the Means of Accuracy of Written Performance in Planned and Unplanned Complex Task

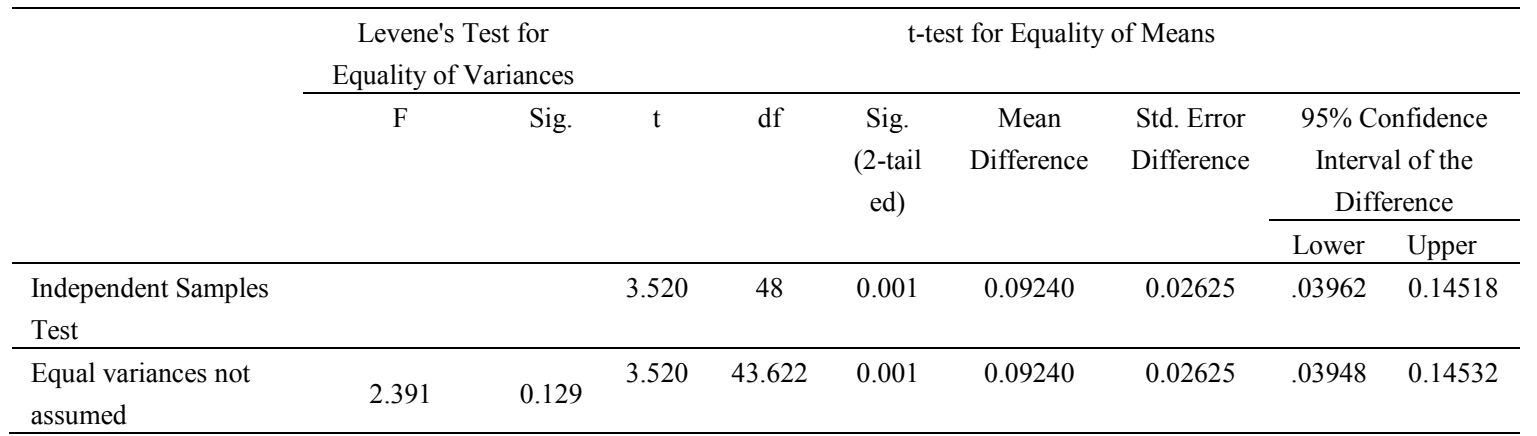

Table 6 shows the results of statistical analysis of applying Independent Samples T-test to test the third hypothesis. The results of SPSS at $\mathrm{df}=48$ and $\alpha=.05$, revealed that there was a slight difference between strategic planning and L2 learners' accuracy in complex task. Thus, the third hypothesis claiming "strategic planning time group while performing complex task will produce more accurate written production than unplanned group" is confirmed.

Table 7 shows the means differences of fluency of written performance of the participants of planned and unplanned groups in complex task.

Table 7.Comparison of the Means of Fluency of Written Performance in Planned and Unplanned Complex Task

\begin{tabular}{lcccc}
\hline & $\mathrm{N}$ & Mean & $\begin{array}{c}\text { Std. } \\
\text { Deviation }\end{array}$ & $\begin{array}{c}\text { Std. Error } \\
\text { Means }\end{array}$ \\
\hline $\begin{array}{l}\text { Planned Fluency } \\
\text { Complex }\end{array}$ & 25 & 11.7820 & 1.92270 & 0.38454 \\
\hline $\begin{array}{l}\text { Unplanned Fluency } \\
\text { Complex }\end{array}$ & 25 & 10.5652 & 1.54742 & 0.30948 \\
\hline
\end{tabular}

The data provided in table 7 reveals that the participants of planned group produced more fluent (11.78) language than unplanned group in complex task (10.56).

Figure 4 also shows the means differences of accuracy for planned and unplanned groups in complex task. 
International Journal of Applied Linguistics \& English Literature

ISSN 2200-3592 (Print), ISSN 2200-3452 (Online)

Vol. 1 No. 7; November 2012 [Special Issue on Applied Linguistics]

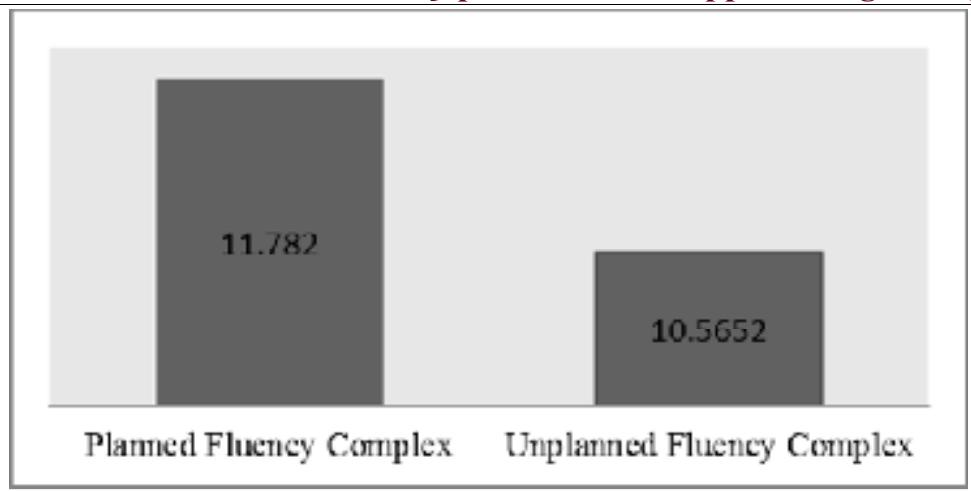

Figure 4. Comparison of the Means of Fluency of Written Performance in Planned and Unplanned Complex Task

Table 8 Independent Samples T-Test for the Means of Fluency of Written Performance in Planned and Unplanned Complex Task

\begin{tabular}{|c|c|c|c|c|c|c|c|c|c|}
\hline & \multicolumn{2}{|c|}{$\begin{array}{c}\text { Levene's Test for } \\
\text { Equality of Variances }\end{array}$} & \multicolumn{7}{|c|}{ t-test for Equality of Means } \\
\hline & \multirow[t]{2}{*}{$\mathrm{F}$} & \multirow[t]{2}{*}{ Sig. } & \multirow[t]{2}{*}{$\mathrm{t}$} & \multirow[t]{2}{*}{$\mathrm{df}$} & \multirow[t]{2}{*}{$\begin{array}{l}\text { Sig. } \\
\text { (2-taile } \\
\text { d) }\end{array}$} & \multirow[t]{2}{*}{$\begin{array}{c}\text { Mean } \\
\text { Difference }\end{array}$} & \multirow[t]{2}{*}{$\begin{array}{l}\text { Std. Error } \\
\text { Difference }\end{array}$} & \multicolumn{2}{|c|}{$\begin{array}{c}95 \% \text { Confidence } \\
\text { Interval of the } \\
\text { Difference }\end{array}$} \\
\hline & & & & & & & & Lower & Upper \\
\hline $\begin{array}{l}\text { Independent } \\
\text { Samples Test }\end{array}$ & & & 2.465 & 48 & 0.017 & 1.21680 & 0.49361 & 0.22433 & 2.20927 \\
\hline $\begin{array}{l}\text { Equal variances } \\
\text { not assumed }\end{array}$ & 0.216 & 0.644 & 2.465 & 45.902 & 0.017 & 1.21680 & 0.49361 & 0.22316 & 2.21044 \\
\hline
\end{tabular}

Table 8 shows the results of statistical analysis of applying Independent Samples T-test to test the fourth hypothesis. The results of SPSS at $\mathrm{df}=48$ and $\alpha=.05$, revealed that there was a significant difference between strategic planning and L2 learners' fluency in complex task. Thus, the fourth hypothesis claiming "strategic planning time group while performing complex task will produce more fluent language production than unplanned group" is confirmed.

\section{Discussion and Conclusions}

Regarding the effects of strategic planning and task complexity on L2 learners' written production in terms of accuracy in simple task, it was revealed that strategic planning in simple task led to more accuracy. That is, the participants who performed simple task with strategic pre-task planning produced more accurate language than the participants who performed simple task without strategic pre-task planning. Thus, our first hypothesis is confirmed. The findings of the study in terms of accuracy are in agreement with the findings of studies like Foster and Skehan (1996), Foster (1997), Ortega (1999), Tavakoli and Skehan (2005), and Ishikawa (2006). However, the findings of the present study in terms of accuracy ran against the findings of the studies like Gilabert (2005), Mehrang and Rahimpour (2010), Hosseini and Rahimpour (2010), and Salimi and Dadashpour (2012). These findings in terms of accuracy can be interpreted in Levelt's (1989) terms, the lighter processing load for the Conceptualizer, the more "space" for the Formulator to work within. Therefore, the Formulator can give more attention to grammatical accuracy, and performance is subsequently more accurate.

Considering the effect of strategic planning time and task complexity on L2 learners' written performance in terms of fluency in simple task, the findings of the study and the results of data analysis revealed that planning time had a positive effect on the participants' written fluency in simple task. The findings of the study in terms of fluency are in line with Crookes (1989), Foster and Skehan (1996), Robinson, Ting and Urwin (1996), Ortega (1999), Tavakoli and Skehan (2005), Gilabert (2005), Ishikawa (2006), and Salimi and Dadashpour (2012b). However, the findings of the present study in terms of fluency were in odds with the findings of the studies like Mehrang and Rahimpour (2010) and Robinson (2001). These findings can be attributed to the findings of Skehan (1998) who claimed that trade-off effects are likely to occur between different aspects of language production as 
International Journal of Applied Linguistics \& English Literature

ISSN 2200-3592 (Print), ISSN 2200-3452 (Online)

Vol. 1 No. 7; November 2012 [Special Issue on Applied Linguistics]

a result of human's limited attentional resources (i.e. learners are not able to pay a balanced attention to different aspects of language simultaneously).

Regarding the effects of strategic planning and task complexity on L2 learners' written production in terms of accuracy in complex task, the findings of the study revealed that there was a trend towards significance between strategic planning and written accuracy of learners in complex task. The findings of the study in terms of accuracy are in agreement with the findings of studies like Foster and Skehan (1996), Foster (1997), Ortega (1999), Tavakoli and Skehan (2005), and Ishikawa (2006). However, the findings of the present study in terms of accuracy ran against the findings of the studies like Gilabert (2005), Mehrang and Rahimpour (2010), Hosseini and Rahimpour (2010), and Salimi and Dadashpour (2012). The higher rate of accuracy in complex task can be interpreted in terms of Long's view (1985) that a difficult task will lead learners to stretch their interlanguage resources. The accuracy can also be interpreted in terms of Givon's (1989) pragmatic and syntactic modes demanding learners to use greater syntactic resources and abilities which will lead to an increase in grammatical accuracy. The accuracy can also be attributed to the load of attention paid by the learners to the difficult task than paid to the easy task.

Considering the effect of strategic planning time and task complexity on L2 learners' written performance in terms of fluency in complex task, the findings of the study revealed that planning time had a significant effect on written fluency in complex task. The findings of the study in terms of fluency are in line with Foster and Skehan (1996), Robinson, Ting and Urwin (1996), Ortega (1999), Tavakoli and Skehan (2005), Gilabert (2005), Ishikawa (2006), and Salimi and Dadashpour (2012b). However, the findings of the present study in terms of fluency are in odds with the findings of the studies like Mehrang and Rahimpour (2010) and Robinson (2001). These findings can be considered as partial support to Skehan (1998) who claimed that trade-off effects are likely to occur between different aspects of language production as a result of human's limited attentional resources (i.e. learners are not able to pay a balanced attention to different aspects of language simultaneously). This increase in both fluency and accuracy in simple and complex tasks supports the effectiveness of the provision of planning time in task performance.

\section{Pedagogical implications}

This study carries some implications for second language acquisition (SLA) researchers, language teachers in their practices in teaching, and syllabus designers. As mentioned earlier, one of the major issues regarding task-based language teaching and learning is to find out how learners allocate attention between the competing goals of fluency, accuracy and complexity and therefore, establish a balance between these performance areas. So, the findings make it possible for a teacher or more importantly for a syllabus designer to design sequences of instructional activities that alternate attention to each of the areas so that the goal of balanced development can be obtained. Also, the findings of this study can contribute to task-based teaching methodology since planning is considered as one of the task implementation factors that can be manipulated by giving chance or not providing time for planning, offering different types of planning to the learners in task performance, and providing learners with various lengths of planning time and planning effects can be observed in the performance of language learners (Ellis, 2009). These findings may also add to the present literature in SLA theory, syllabus design, and material development.

\section{References}

Anderson, A. and Lynch, T. (1988). Listening. Oxford: Oxford University Press.

Arent, R. (2003). Promoting revision and development in L2 writing through a combination- based curriculum. The Korea TESOL Journal, 6(1), 1-26.

Breen, M. P. (2001). Syllabus design. In R. Carter and D. Nunan (Eds.), The Cambridge guide to teaching English to speakers of other languages (pp.151-159). Cambridge: Cambridge University Press.

Brindley, J. (1987). Factors affecting task difficulty. In D. Nunan, (Ed.), Guidelines for the development of curriculum resource (pp.45-56). Adelaide: National Curriculum Resource Center.

Brown, R., and Bellugi, U. (1964). 'Three processes in the child's acquisition of syntax'. Harvard Educational Review, 34, 133-151.

Brown, G., and Yule, G. (1983). Teaching the spoken language: an approach based on the analysis of conversational English. Cambridge: Cambridge University Press. 


\section{International Journal of Applied Linguistics \& English Literature}

ISSN 2200-3592 (Print), ISSN 2200-3452 (Online)

Vol. 1 No. 7; November 2012 [Special Issue on Applied Linguistics]

Bygate, M., Skehan, P. and Swain, M. (2001). 'Introduction' in M.Bygate, P. Skehan and M. Swain (Eds.). Researching pedagogic tasks, second language learning, teaching and testing. Harlow: Longman.

Candlin, C. (1987). Towards task-based language learning. In Candlin, C. and Murphy, D. (Eds.), Language Learning Tasks (pp.5-22). Englewood Cliffs, NJ: Prentice Hall.

Clark, H., and Clark, G. (1977). Psychology and language: An introduction to psycholinguistics. New York NY: Harcourt, Brace, Jovanovich.

Crookes, G. (1989). Planning and interlanguage variation. Studies in Second Language Acquisition, 11, 367-383.

Dadashpour, S. (2011). The Effects of Task Complexity on EFL Learners' Written Performance. Unpublished master's thesis, Islamic Azad University, Maragheh Branch, Maragheh, Iran.

Das, J. P., Kar, B. C., and Parrilla, R. K, (1996). Cognitive planning: the psychological basis of intelligent behavior. New Delhi: Sage.

Elder, C., and Wigglesworth, G. (2003). An investigation of the effectiveness and validity of planning time in Part 2 of the IELTS Speaking Test. IELTS Research Reports, 6, 1-28.

Ellis, R. (2003). Task-based language learning and teaching. Oxford: Oxford University Press.

Ellis, R (Ed.) (2005). Planning and task performance in a second language. Amsterdam: John Benjamins .

Ellis, R. (2008). The study of second language acquisition. Oxford: Oxford University Press.

Ellis, R. (2009). Task-based language teaching: Sorting out the misunderstandings. International Journal of Applied Linguistics 19 (3), 229-246.

Ellis, R., and Yuan, F. (2004). The effects of planning on fluency, complexity, and accuracy in second language narrative writing. Studies in Second ALnaguge Acquisition, 26, 59-84.

Foster, P., and Skehan, P. (1996). The influence of planning and task type on second language performance. Studies in Second Language Acquisition, 9, 12-20.

Foster, P., and Skehan, P. (1999). The influence of planning and focus of planning on task-based performance. Language Teaching Research, 3, 215-247.

Gilabert, R. (2005). Task complexity and L2 narrative oral production. Unpublished Ph.D. dissertation. University of Barcelona, Spain.

Gilabert, R. (2007). Effects of manipulating task complexity on self-repairs during L2 oral production. International Review of Applied Linguistics, 45, 215-240.

Givon, T. (1989). Mind, code, and context. essays in pragmatics. Hillsdale, NJ: Erlbaum.

Hosseini, P. and Rahimpour, M. (2010). The Impact of Task Complexity on L2 Learners' Written Narratives, CCSE, 3 (3), 198-205.

Ishikawa, T. (2006). The effects of task complexity and language proficiency on task- based language performance. The Journal of Asia TEFL, 3(4), 193-225.

Philp, J., Oliver, R., and Mackey, A. (2006). The impact of planning time on children's task-based interactions. System, 34, 547-565.

Kim, Y. (2009). The effects of task complexity on learner-learner interaction. System, 37,254-268.

Kuiken, F., and Vedder, I. (2007). Task complexity and measures of linguistic performance in L2 writing. International Review of Applied Linguistics, 45(3), 261-284.

Kuiken, F., and Vedder, I. (2008). Cognitive task complexity and written output in Italian and French as a foreign language. Journal of Second Language Writing, 17, 48-60.

Levelt, W. (1989). Speaking: From intension to articulation. Cambridge MA: The MIT Press.

Long, M. (1985). A role for instruction in second language acquisition: task-based language teaching. In K. Hyltenstam and M. Pienemann (Eds.), Modelling and assessing second language acquisition (pp.77-99). Clevedon: Multilingual Matters.

Long, M. (Ed.) (2007) .Problems in SLA, Mahwah, NJ: Erlbaum. 
International Journal of Applied Linguistics \& English Literature

ISSN 2200-3592 (Print), ISSN 2200-3452 (Online)

Vol. 1 No. 7; November 2012 [Special Issue on Applied Linguistics]

Long, M., and Crookes, G. (1992). Three approaches to task-based syllabus design. TESOL Quarterly, 26(1), 27-56.

Mehnert, U. (1998). The effects of different lengths of time for planning on second language performance. Studies in Second Language Acquisition, 20, 83-108.

Mehrang, F. and Rahimpour, M. (2010). The impact of task structure and planning conditions on oral performance of EFL learners. Social and Behavioral Sciences, 2, 3678-3686.

Meisel, J. (1987). Reference to past events and actions in the development of natural language acquisition. In C. Pfaff (Ed.), First and second language acquisition processes (pp.206-224). Cambridge, MA: Newbury House.

Nunan, D. (1989). Designing tasks for the communicative classroom. Cambridge: Cambridge University Press.

Ortega, L. (1999). Planning and focus on form in L2 oral performance. Studies in Second Language Acquisition, 21, 109-148.

Pieneman, M. (1985). 'Learnability and syllabus construction in K. Hyltenstam and M. Pienemann (eds.): Modeling and Assessing Second Language Acquisition. Clevedon, Avon: Multilingual Matters.

Prabhu, N. S. (1987). Second language pedagogy. Oxford: Oxford university press.

Rahimpour, M. (1997). Task complexity, task condition, and variation in L2 oral discourse. Unpublished Ph.D. thesis, University of Queensland, Australia.

Rahimpour, M. (1999). Task complexity and variation in interlanguage. In N. O. Jungheim\&P. Robinson (Eds.), Pragmatic and pedagogy: proceeding of the $3^{\text {rd }}$ pacific Second Language Research Forum (pp.115-134). Tokyo, Japan: Pac LRF.

Rahimpour, M. (2002). Factors affecting task difficulty. Journal of the Faculty of Literature and Humanities, Tarbiat Moallem University, 9(33), 1-16.

Rahimpour, M. (2008). Implementation of task-based approaches to language teaching. Pazhuhesh-e-Zabanha-ye Khareji Journal, University of Tehran, 41, 45-61.

Rahimpour, M. (2010). Current trends on syllabus design in FL instruction. Procedia Social and Behavioral Sciences, 2, 1660-64.

Robinson, P. (1995). Task complexity and second language narrative discourse. Language Learning, 45(1), 99-140.

Robinson, P. (2001). Task complexity, task difficulty, and task production: exploring interactions in a componential framework, Applied Linguistics, 22(1), 27-57.

Robinson, P. (2003). The cognition hypothesis, task design, and adult task-based language learning. Second Language Studies, 21(2), 45-105.

Robinson, P. (2005). Cognitive complexity and task sequencing: studies in a componential framework for second language task design. International Review of Applied Linguistics, 43, 1-32.

Robinson, P. (2007). Triadic framework for TBLT: Task complexity, task difficulty, and task condition. The Journal of Asia TEFL, 195-225.

Robinson, P., Chi-chien Ting, S. and Urwin, J. (1995). Investigating second language task complexity. RELC, 26, 62-78.

Salimi, A. and Dadashpour, S. (2010). Task complexity and L2 learners' written performance. A paper presented at WCCES 14. Bogazici University, Istanbul, Turkey, 14-18 June.

Salimi, A. and Dadashpour, S. (2012a). Task complexity and SL development: Does task complexity matter? Procedia-Social and Behavioral Sciences, 46, 726-735.

Salimi, A. and Dadashpour, S. (2012b). Task Complexity and Language Production Dilemmas (Robinson's Cognition Hypothesis vs. Skehan's Trade-off Model). Procedia-Social and Behavioral Sciences, 46, 643-652.

Salimi, A., Dadashpour, S., and Asadollahfam, H. (2011). The Effect of Task Complexity on EFL learners' written performance. Social and Behavioral Sciences, 29, 1390-1399.

Salimi, A., Shafaei, A. and Kuhi, D. (2011). The Impact of the generic features of tasks on L2 learners' written production. A Procedia-Social and Behavioral Sciences, 46, 653-662. 
International Journal of Applied Linguistics \& English Literature

ISSN 2200-3592 (Print), ISSN 2200-3452 (Online)

Vol. 1 No. 7; November 2012 [Special Issue on Applied Linguistics]

Schmidt, R. (2001). Attention. In Robinson, P. (Ed.), Cognition and second language instruction. Cambridge: Cambridge University Press.

Shafaei, A. (2012). The effect of generic features of task on L2 learners' oral performance in EFL context. Unpublished master's thesis, Islamic Azad University, Maragheh Branch, Maragheh, Iran.

Skehan, P. (1996). A framework for the implementation of task-based instruction.Applied Linguistics, 17(1), 38-62.

Skehan, P. (1998). A cognitive approach to language learning. Oxford: Oxford University Press.

Skehan, P. and Foster, P. (1999). The influence of task structure and processing conditions on narrative retellings. Language Learning, 49(1), 93-120.

Tavakoli, P., and Foster, P. (2008). Task design and second language performance: the effect of narrative type on learner output. Language Learning, 58(2), 439-473.

Tavakoli, p., and Skehan, P. (2005). Strategic planning, task structure, and performance testing. In R. Ellis (Ed.), Planning and task performance in a second language (pp. 239 - 277). Amsterdam: Benjamins.

Tarone, E. (1983). On the variability of interlanguage systems. Applied Linguistics, 4, 143-63.

Wang, Y, (2008). Influence of Planning on Students' Language Performance in Task-based Language Teaching. English language Teaching, 1 (1), 83-86.

Yuan, F. (2001). The effects of planning on language production in task-based language teaching. Doctoral thesis, Temple University.

Yuan, F., and Ellis, R. (2003). The effects of pre-task planning and on-line planning on fluency, complexity and accuracy in L2 monolgic oral production. Applied Linguistics, 24 (1), 1-27. 